\title{
Retraction
}

\section{Retracted: Lentivirus-Mediated siRNA Targeting ER- $\alpha$ Inhibits Tumorigenesis and Induces Apoptosis in Hepatocarcinoma Cells}

\author{
BioMed Research International \\ Received 20 October 2020; Accepted 20 October 2020; Published 24 November 2020 \\ Copyright (c) 2020 BioMed Research International. This is an open access article distributed under the Creative Commons \\ Attribution License, which permits unrestricted use, distribution, and reproduction in any medium, provided the original work \\ is properly cited.
}

BioMed Research International has retracted the article titled "Lentivirus-Mediated siRNA Targeting ER- $\alpha$ Inhibits Tumorigenesis and Induces Apoptosis in Hepatocarcinoma Cells" [1] due to an error in the gene targeting.

It was raised to our attention [2] that the siRNA sequence said to target ER- $\alpha$ (estrogen receptor alpha), $5^{\prime}$ GCCTTACAATGTACA GCAGAA $-3^{\prime}$, instead targets the similarly named but unrelated gene ERAL1 (Era Like 12S Mitochondrial RRNA Chaperone 1) [3].

Over 300 words, including the discussion of the use of siRNA, overlap with an article by other authors that was not cited, which also studied lentivirus-mediated RNA inference in hepatocarcinoma cells [4]. The file properties show the manuscript was edited by someone who is not one of the authors. The authors could not be contacted.

\section{References}

[1] P. Jiang, J. Cao, and W.-H. Bai, "Lentivirus-Mediated siRNA Targeting ER- $\alpha$ Inhibits Tumorigenesis and Induces Apoptosis in Hepatocarcinoma Cells," BioMed Research International, vol. 2015, Article ID 490681, 8 pages, 2015.

[2] C. Labbé, N. Grima, T. Gautier, B. Favier, and J. A. Byrne, "Semi-automated fact-checking of nucleotide sequence reagents in biomedical research publications: the seek \& Blastn tool," PLoS One, vol. 14, no. 3, article e0213266, 2019.

[3] ERAL1 Gene, GeneCardshttps://www.genecards.org/cgi-bin/ carddisp.pl?gene $=$ ERAL1.

[4] J. Qin, Y. Xu, X. Li et al., "Effects of lentiviral-mediated Foxp1 and Foxq1 RNAi on the hepatocarcinoma cell," Experimental and Molecular Pathology, vol. 96, no. 1, pp. 1-8, 2014. 